Jurnal Sain Veteriner, Vol. 37. No. 1. Juni 2019, Hal. 17-26

DOI : $10.22146 /$ jsv. 22324

ISSN 0126-0421 (Print), ISSN 2407-3733 (Online)

Tersedia online di https://jurnal.ugm.ac.id/jsv

\title{
Studi Reseptor Virus Infectious Bursal Disease (IBD) pada Organ Limfoid Ayam Pasca Vaksinasi dengan Metode Imunohistokimia
}

\section{The Study of Infectious Bursal Disease (IBD) Virus recemor at chiken Lymphoid Organ after vaccination by Immunahistochemistry Method}

\author{
Restu Librani $^{1}$, Agus Setiyono ${ }^{2}$, Wiwin Winarsih ${ }^{2}$ \\ ${ }^{1}$ Fakultas Peternakan Universitas Halu Oleo, Jln. H.E.A Mokodompit Kambu Kendari \\ ${ }^{2}$ Bagian Patologi, Departemen Klinik Reproduksi dan Patologi, \\ Fakultas Kedokteran Hewan, Institut Pertanian Bogor \\ E-mail: libriani.restu@gmail, agusetiyo@yahoo.com; patoipb@indo.net.id
}

Naskah diterima : 24 Februari 2017, direvisi : 22 Januari 2019, disetujui : 29 Januari 2019

\begin{abstract}
Infectious bursal disease (IBD) affects economical impact for breeders due to it can cause damage lymphoid organ, especially bursa of Fabricius and causing failure the vaccination program. Infectious bursal disease virus receptors on lymphoid organs suspected contribute to subclinical and clinical IBD incidence in the chickens. The aim of this study was to determine and compare the distribution of IBDvirus receptors on lymphoid organ of the chicken which obtained different IBD vaccination program. The presence of virus receptors in bursa of Fabricius, spleen, and thymus were observed microscopically using immunohistochemical method and evaluated with Image J® software. Monoclonal anti LSCC-BK3 (Gifu University, Japan) antibodies as primary antibody was used in this study. The result showed that IBDvirus receptors found abudantly in the bursa of Fabricius, afterwards in the spleen and thymus. No significant differences of IBD virus receptor distribution within lymphoid organs between chicken which obtained once and twice IBD vaccination. Infectious bursal disease virus receptor distribution in bursa Fabricius chickens aged 23 days received twice IBD vaccination more than once IBD vaccination program.
\end{abstract}

Keywords: chickens; IBD; immunohistochemistry; receptor; vaccination

\begin{abstract}
Abstrak
Kejadian infectious bursal disease (IBD) berdampak ekonomi bagi peternak karena dapat merusak organ limfoid terutama bursa Fabricius dan menyebabkan kegagalan program vaksinasi. Reseptor virus IBD pada organ limfoid diduga berkontribusi terhadap kejadian subklinis dan klinis IBD pada ayam. Tujuan penelitian ini adalah untuk mengetahui sebaran reseptor virus IBD pada organ limfoid ayam yang mendapat vaksin IBD yang berbeda. Sebaran reseptor pada bursa Fabricius, limpa, dan timus diamati secara mikroskopis menggunakan metode imunohistokimia dan dievaluasi menggunakan perangkat lunak Image $J ®$. Penelitian ini menggunakan antibodi monoklonal anti sel LSCC-BK3 (Gifu University, Japan) sebagai antibodi primer. Hasil penelitian menunjukan bahwa reseptor virus IBD banyak ditemukan pada bursa Fabricius kemudian limpa dan timus. Sebaran reseptor virus IBD pada organ limpa dan timus ayam yang mendapat program vaksinasi 1 kali tidak berbeda nyata dengan ayam yang mendapat program vaksinasi IBD 2 kali. Sebaran reseptor virus IBD pada organ bursa Fabricius ayam umur 23 hari yang mendapat program vaksinasi 2 kali lebih banyak dibandingkan ayam yang mendapat program vaksinasi IBD 1 kali.
\end{abstract}

Kata kunci: ayam; IBD; imunohistokimia; reseptor; vaksinasi

\section{Pendahuluan}

Infectious bursal disease (IBD) atau gumboro merupakan penyakit infeksius pada unggas yang bersifat akut (Van den Berg et al. 2000). Agen penyebab penyakit ini adalah virus genus
Avibirnavirus famili Birnaviridae yang mempunyai asam inti RNA rantai ganda dengan dua segmen (A dan B) (Muller et al. 1979). Virus IBD merupakan virus limfotropik yang dapat merusak limfosit B (immature) secara cepat dan menyebabkan imunosupresi pada 
unggas (Uddin et al 2012).

Pada ayam Specific-pathogen-free (SPF) yang diinfeksi virus IBD strain yang patogenik (intramuscular) terlihat bahwa virus merusak sel B secara cepat pada bursa Fabricius kemudian replikasi virus meluas disertai dengan infiltrasi sel T pada bursa Fabricius (Kim et al., 2000). Replikasi virus IBD pertama kali pada limfosit dan makrofag (Kaufer dan Weiss, 1976) pada mukosa yang berhubungan dengan jaringan limfoid di duodenum, jejunum dan sekum, kemudian bereplikasi pada sel limfosit B (immature) bursa Fabricius dan organ limfoid lainnya seperti limpa dan timus (Van den Berg et al., 2000). Virus IBD menekan respon imun ayam terinfeksi sehingga menjadi rentan terhadap infeksi sekunder serta dapat mengakibatkan kegagalan vaksinasi (Van den Berg et al., 2000). Selain itu, virus IBD dapat menyebabkan morbiditas yang tinggi mencapai 100\% dan mortalitas antara 20 sampai $30 \%$, sedangkan untuk virus very virulent IBD (vvIBD) tingkat morbiditas dan mortalitasnya dapat mencapai 100\% (Enterradossi and Saif, 2008; Wahyuwardani dkk. 2011).

Penyebaran virus IBD dapat melalui kontaminasi pakan dan air minum. Ayam yang terinfeksi umumnya berumur 3-6 minggu dengan gejala klinis antara lain anoreksia, depresi, diare, imunosupresi, dan lesio pada bursa. Ayam kurang dari 3 minggu tidak menunjukkan gejala klinis (subklinis) namun menyebabkan imunosupresi. Kematian sering disebabkan oleh dehidrasi yang disertai dengan lesio pada ginjal. Selama fase akut, bursa Fabricius mengalami deplesi sel B dan atropi. Antigen virus banyak ditemukan pada folikel bursa Fabricius dan organ limfoid lainnya seperti limpa dan timus (Smith et al., 2014).

Banyaknya kejadian IBD dengan tingkat morbiditas dan mortalitas yang cukup tinggi serta adanya kejadian klinis dan subklinis yang bersifat imunosupresi menyebabkan penyakit ini menarik untuk dikaji lebih mendalam. Setiyono et al. (2000) dalam penelitiannya mengisolasi antibodi monoklonal (AbMo) yang dapat menghambat infeksi virus IBD pada sel LSCC-BK3. Sel LSCC-BK3 (BLymphoblastoid cell line) adalah sel lestari limfoblastoid B pada ayam yang dapat diinfeksi virus IBD (Setiyono et al., 2001). Reseptor pada LSCC-BK3 dikenali sebagai protein $\mathrm{N}$-Glycosylated (Ogawa et al. 1998). Antibodi monoklonal anti sel LSCC-BK3 tersebut dapat digunakan untuk mempelajari reseptor virus IBD pada organ limfoid ayam dengan metode imunohistokimia (IHK). Berkaitan dengan hal tersebut, penelitian yang berjudul Studi Reseptor Virus Infectious Bursal Disease (IBD) pada Organ Limfoid Ayam pasca vaksinasi dengan Metode Imunohistokimia ini dilakukan.

Sebaran reseptor virus IBD pada organ limfoid ayam yang mendapat vaksin IBD yang berbeda akan dideteksi menggunakan metode IHK dengan antibodi primer anti sel LSCC-BK3. Penelitian ini juga bertujuan untuk mengevaluasi sebaran reseptor virus IBD pada organ limfoid ayam pasca vaksinasi di lapangan dan mempelajari kejadian klinis dan subklinis IBD pada ayam.

\section{Materi dan Metode}

Penelitian ini menggunakan sampel organ limfoid (bursa Fabricius, limpa, dan timus) ayam broiler, AbMo anti sel LSCC-BK3 sebagai antibodi primer (GifuUniversity, Japan), dan Kit Envision ${ }^{\mathrm{TM}}$ Detection Systems Peroxidase/DAB, Rabbit/Mouse DACO. Pewarnaan Hematoksilin Eosin. Vaksin inaktif (kill) dengan isolat lokal, Tasik strain (951) dan vaksin aktif(live) intermediate plus. Peralatan yang digunakan pada penelitian ini antara lain automatic tissue processor, parafin block, dan mikrotom.

Sampel yang digunakan pada penelitian ini 
adalah bursa Fabricius, limpa, dan timus dari ayam broiler di peternakan ayam di Kabupaten Sukabumi, Jawa Barat. Ayam yang diambil adalah ayam sehat yang dicirikan dengan terlihat aktif bergerak, bulu bersih dan mengkilat, tidak ada discharge pada mata atau nasal, anus bersih, BB normal pada populasi. Organ limfoid yang diambil terlihat normal secara patologi anatomi.

Pembagian kelompok didasarkan pada perbedaan umur saat dilakukan diterminasi dan program vaksinasi yang diterapkan di peternakan. Program vaksinasi yang diterapkan yaitu program vaksinasi 1 kali yang diberikan pada ayam umur 11 hari (vaksin aktif, air minum) dan program vaksinasi 2 kali yang diberikan pada ayam umur 4 hari (vaksin inaktif, subkutan) dan umur 11 hari (vaksin aktif, air minum).

Ayam diterminasi pada umur 8, 15, dan 23 hari pada masing-masing program vaksinasi IBD yang diterapkan. Sebanyak 18 ekor ayam broiler yang digunakan dikelompokkan menjadi $6 \quad(n=3)$. Kelompok I sampai III untuk ayam berumur 8, 15, dan 23 hari dengan program vaksinasi 1 kali, kelompok IV sampai VI untuk ayam berumur 8, 15, 23 hari dengan program vaksinasi IBD 2 kali (Gambar 1)

Sebelum dinekropsi ayam diditerminasi dengan disembelih. Selanjutnya diambil organ timus, limpa, dan bursa Fabricius. Organ-organ tersebut dimasukkan ke dalam wadah plastik yang berisi larutan bufferd neutral formalin (BNF) 10\% dan diberi label. Setelah organ terfiksasi dengan baik di dalam larutan BNF $10 \%$, organ siap diproses secara histopatologi dan diwarnai dengan pewarnaan hematoksilin-eosin (HE) dan imunuhistokimia (IHK). Pewarnaan HE untuk mendeskripsikan lesio yang ditemukan pada organ dan IHK untuk mendeteksi antigen reseptor virus IBD pada organ limfoid.
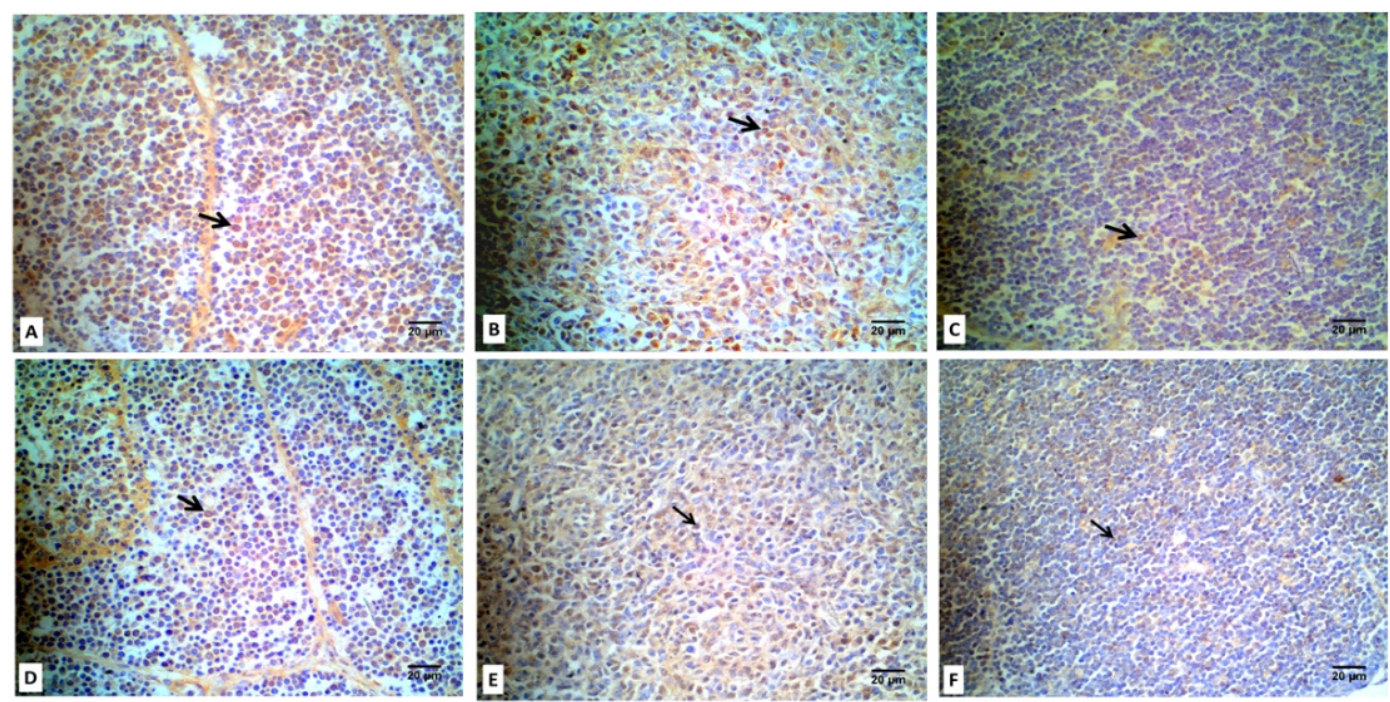

Gambar 1. Diagram pembagian kelompok penelitian

Pengamatan mikroskopis berupa sebaran reseptor virus IBD pada organ limfoid ayam yang terlihat positif berwarna coklat dengan pewarnaan IHK dan lesio pada organ yang diamati menggunakan pewarnaan HE berbasis skoring.

Data dianalisis secara deskriptif dan kuantitatif menggunakan perangkat lunak Image $J 囚$ analisis gambar untuk program Microsoft $\AA$ Windows ${ }^{\circledR}$. Reseptor dihitung per $1000 \mu \mathrm{m}^{2}$ pada 10 lapang pandang. Selanjutnya dilakukan uji statistik dengan menggunakan perangkat lunak SAS untuk Microsoft ${ }^{\circledR}$ Windows ${ }^{\circledR}$, yaitu dengan metode analisis ragam ANOVA dan dilanjutkan dengan uji Duncan untuk menganalisa perbedaan antar kelompok. Data 
non-parametrik pada skor lesio histopatologi dilakukan analisa menggunakan uji Kruskall wallis yang dilanjutkan dengan Mann whitney U test dan Dunn's test untuk menguji perbedaan antar kelompok.

\section{Hasil dan Pembahasan}

Rataan sebaran reseptor virus IBD ayam pada kelompok yang mendapat vaksinasi IBD 1 kali dan 2 kali pada umur 8, 15, dan 23 hari disajikan pada Tabel 1.

Tabel 1. Jumlah sebaran reseptor virus IBD pada organ bursa Fabrisius, limpa, dan timus (per $1000 \mu \mathrm{m}^{2}$ )

\begin{tabular}{ccccccc}
\hline & \multicolumn{5}{c}{ Kelompok Perlakuan } \\
\cline { 2 - 7 } Vaksinasi IBD 1 kali & \multicolumn{5}{c}{ Vaksinasi IBD 2 kali } \\
\hline $\begin{array}{c}\text { Organ/ } \\
\begin{array}{c}\text { Umur } \\
\text { hari }\end{array}\end{array}$ & 8 & 15 & 23 & $8^{*}$ & $15^{*}$ & $23^{*}$ \\
\hline Bursa & $5.45 \pm 0.32^{\mathrm{Aal}}$ & $4.42 \pm 1.00^{\mathrm{Aal}}$ & $5.21 \pm 0.16^{\mathrm{Aal}}$ & $5.78 \pm 1.09^{\mathrm{Adl}}$ & $4.22 \pm 0.48^{\mathrm{AdI}}$ & $6.15 \pm 0.44^{\mathrm{BdI}}$ \\
\hline Limpa & $3.80 \pm 1.10^{\mathrm{Aa} 2}$ & $2.82 \pm 0.80^{\mathrm{Aal}}$ & $3.86 \pm 1.01^{\mathrm{Aa} 2}$ & $3.28 \pm 0.87^{\mathrm{Ad} 2}$ & $2.53 \pm 0.19^{\mathrm{Ad} 2}$ & $4.04 \pm 1.23^{\mathrm{Ad} 2}$ \\
\hline Timus & $2.62 \pm 0.08^{\mathrm{Aa} 2}$ & $2.46 \pm 1.14^{\mathrm{Aa} 1}$ & $2.65 \pm 0.37^{\mathrm{Aa} 2}$ & $2.55 \pm 1.34^{\mathrm{Ad} 2}$ & $2.60 \pm 0.63^{\mathrm{Ad} 2}$ & $2.94 \pm 0.40^{\mathrm{Ad} 2}$ \\
\hline
\end{tabular}

\footnotetext{
${ }^{\mathrm{AB}}$ Huruf berbedapada baris yang sama untuk kelompok umur yang sama berbeda nyata $(\mathrm{P}<0.05)$

${ }^{\text {ab }}$ Huruf berbeda pada baris yang sama berbeda nyata $(\mathrm{P}<0.05)$ (vaksinasi IBD 1 kali)

${ }^{d e *}$ Huruf berbeda pada baris yang sama berbeda nyata $(\mathrm{P}<0.05)$ (vaksinasi IBD 2 kali)

${ }^{12}$ Angka berbedapada kolom yang sama berbeda nyata $(\mathrm{P}<0.05)$
}

Hasil penelitian menunjukkan bahwa sebaran reseptor virus IBD pada program vaksinasi IBD 1 kali ayam umur 8 hari banyak ditemukan pada organ bursa Fabricius dan limpa sedangkan pada ayam umur 23 hari banyak ditemukan pada bursa Fabricius $(\mathrm{P}<0.05)$. Program vaksinasi IBD 2 kali reseptor banyak ditemukan pada organ bursa Fabricius untuk ketiga kelompok umur (Tabel 1). Hal ini sejalan dengan penelitian Ogawa et al. (1998) yang menyebutkan bahwa strain vvIBDV (strain OKYM) berikatan dengan sel limfosit hingga 94\% pada bursa Fabricius, $37 \%$ pada limpa, dan 3\% pada timus. Selain itu, Tippenhauer et al. (2013) menyebutkan bahwa target utama virus IBD adalah organ bursa Fabricius yang menjadi tempat sel limfosit B matang dan berdiferensiasi. Namun demikian, Niepper dan Muller (1996) menjelaskan bahwa replikasi virus IBD tidak hanya terjadi karena adanya reseptor spesifik pada sel limfosit B tetapi terdapat reseptor lain yang dimiliki Chicken Embryo Fibroblasts (CEF) untuk kedua serotipe virus IBD. Kedua serotipe virus IBD berikatan secara spesifik pada protein yang memiliki berat molekul $40 \mathrm{kDa}$ dan $46 \mathrm{kDa}$ yang ada pada permukaan CEF dan sel limfoid. Hirai dan Calnek (1979) menyatakan hanya sebagian sel B yang rentan terhadap infeksi virus IBD dan target spesifik dari infeksi virus IBD adalah sel immunoglobulin M. Selain itu, Virus IBD dapat bereplikasi pada sel limfoid, makrofag, heterofil, sel retikulum dan sel epitel retikular pada bursa Fabricius (Kaufer dan Weiss, 1976). Jumlah reseptor tidak berkorelasi langsung dengan tingginya kejadian infeksi virus IBD, namun adanya reseptor spesifik memungkinkan terjadinya infeksi virus IBD pada unggas.

Sebaran reseptor IBD pada organ bursa Fabricius, limpa, dan timus secara IHK pada kedua program vaksinasi dapat dilihat pada Gambar 2.

Sebaran reseptor IBD pada organ limpa dan timus pada masing-masing kelompok umur antara kedua program vaksinasi IBD tidak memperlihatkan adanya perbedaan yang nyata. Namun, sebaran reseptor IBD pada organ bursa fabricius antar kedua program vaksinasi terlihat berbeda pada ayam umur 23 hari (Tabel 1). Hal ini dimungkinkan karena 
perkembangan sel B limfosit pada ayam umur 8 dan 15 hari belum optimum. Reseptor IBD yang telah aktif dapat berikatan dengan antigen virus IBD dari vaksin sehingga jumlah reseptor IBD yang dikenali IHK semakin sedikit.
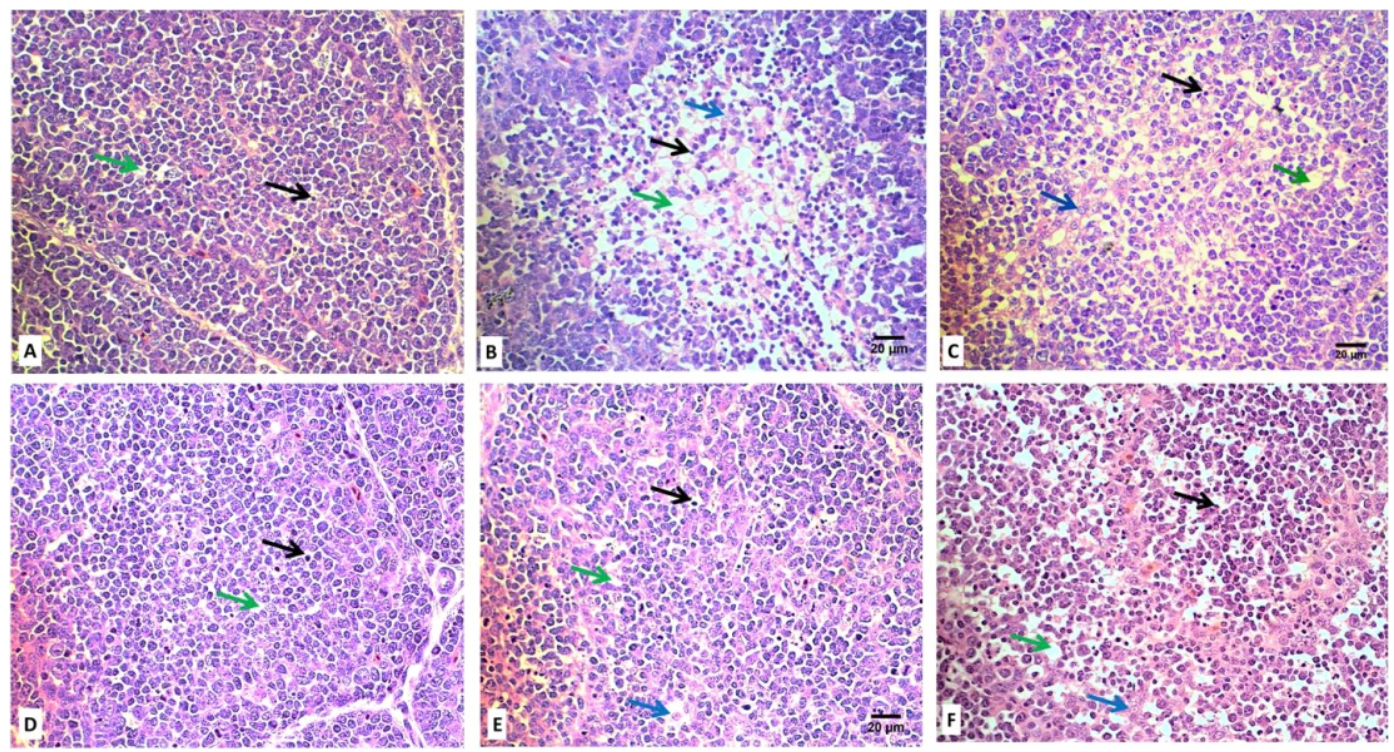

Gambar 2. Representasi foto mikrografi sebaran reseptor virus IBD pada organ limfoid ayam. Positif IHK reseptor virus IBD ( ->). (A) bursa Fabrisius, (B) limpa, dan (C) timus dari ayam yang mendapatkan vaksinasi 1 kali. (D) bursa Fabricius, (E) limpa, dan (F) timus dari ayam yang mendapatkan vaksinasi 2 kali. Pewarnaan IHK.

Pada program vaksinasi IBD 1 dan 2 kali umur 23 hari terlihat adanya peningkatan ekspresi jumlah reseptor IBD. Hal ini dianggap dapat menjelaskan kejadian klinis IBD di lapangan. Semakin banyak virus IBD mampu menempel dan masuk ke sel limfosit maka semakin besar peluang ayam terinfeksi dan mengekspresikan secara klinis IBD. Begitu pula sebaliknya semakin sedikit reseptor dikenali (positif IHK) maka semakin rendah peluang virus dapat menginfeksi ayam (ekspresi subklinis). Smith et al. (2014) menyatakan bahwa ayam kurang dari 3 minggu tidak menunjukkan gejala klinis (subklinis) namun menyebabkan imunosupresi.

Ayam umur 23 hari dengan program vaksinasi 2 kali jumlah reseptor IBD pada organ bursa Fabricius terlihat lebih banyak dari ayam umur 23 hari dengan progam vaksinasi 1 kali. Namun, diduga sel B memori berperan pada meningkatnya jumlah reseptor IBD yang dikenali IHK pada ayam yang mendapat vaksin
IBD 2 kali umur 23 hari sehingga memungkinkan kecilnya peluang ayam terinfeksi virus IBD. Ketika sel naive atau sel $\mathrm{B}$ memori terpapar antigen (dan sel Thelper tidak terlihat), kedua sel tersebut akan berproliferasi dan berdiferensiasi menjadi sel efektor. Sel efektor ini akan memproduksi dan mensekresikan antibodi dengan ikatan yang unik dengan antigen, seperti ikatan antara membran yang memiliki reseptor dengan antibodi (Aberts et al. 2002).

Sebaran reseptor IBD pada organ bursa Fabricius, limpa, maupun timus pada program vaksinasi IBD 1 kali tidak menunjukkan perbedaan yang nyata pada umur yang berbeda $(\mathrm{P}<0.05)$. Namun, terlihat adanya penurunan jumlah ekspresi reseptor IBD pada ayam umur 15 hari (4 hari pasca pemberian vaksin IBD aktif). Pada organ bursa Fabricius, jumlah sebaran reseptor virus IBD pada ayam yang mendapat vaksinasi IBD 2 kali terlihat berbeda nyata antara ayam umur 8 dan 15 hari. Jumlah reseptor IBD pada ayam 
umur 15 hari terlihat lebih sedikit. Hal ini memungkinkan adanya ikatan antara antigen virus vaksin IBD aktif yang diberikan pada ayam umur 11 hari dengan reseptor pada sel limfosit B. Kencana dkk. (2011) dalam penelitiannya menyatakan bahwa vaksin IBD aktif dari strain intermediate dilaporkan menyebabkan sifat imunosupresif pada respon primer vaksin ND. Selain itu, Fantay et al. (2015) menyatakan bahwa waktu yang tepat untuk pemberian vaksin IBD live (intermediate) adalah 18 sampai 21 hari dengan memperhatikan kondisi lingkungan peternakan

Virus IBD dapat merusak organ limfoid terutama bursa Fabricius yang merupakan tempat limfosit B tumbuh kembang dan berdiferensiasi (Davison et al., 2008). Antigen virus yang telah dilemahkan pada vaksin aktif berpotensi menyebabkan adanya kerusakan tersebut. Vaksinasi IBD ayam memperlihatkan adanya lesio ringan pada bursa
Fabricius setelah dilakukan uji tantang (Gao et al. 2011). Banyaknya sel yang mengalami apoptosis berkorelasi dengan kemampuan virus IBD bereplikasi. Selain itu, nekrosis sel juga berperan pada cepatnya kejadian deplesi sel pada bursa Fabricius yang diinfeksi virus IBD (Muller et al., 2003). Pada penelitian ini, pewarnaan $\mathrm{HE}$ digunakan untuk mendeskripsikan adanya lesio dari organ limfoid post vaksinasi IBD. Gaballa et al., 2016 dalam penelitiannya mengemukakan bahwa secara histopatologi ditemukan adanya deplesi folikel limfoid bursa Fabricius yang disertai hemoragi dan hipersellularitas interfolikular.

Gambaran histopatologi organ limfoid ayam yang mendapatkan vaksinasi IBD 1 dan 2 kali itunjukkan pada Gambar 3,4, dan 5. Sedangkan skoring lesio histopatologi dicantumkan pada Tabel 2.
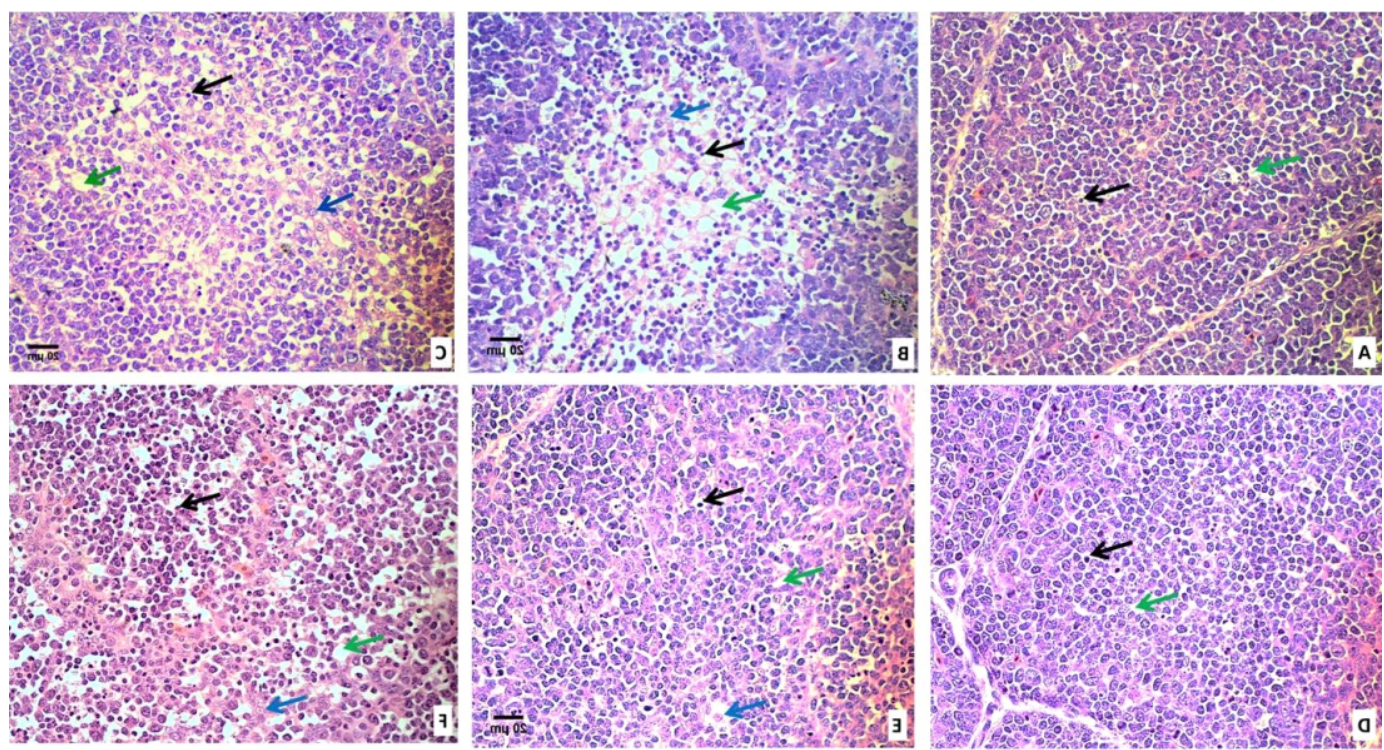

Gambar 3. Foto mikrografi organ bursa Fabricius ayam dengan program vaksinasi IBD 1 kali umur 8 hari (A), umur 15 hari (B), 23 hari (C); dengan program vaksinasi IBD 2 kali umur 8 hari (D), umur 15 hari (E), dan umur 23 hari (F). Deplesi sel

$(\rightarrow)$, udema $(\rightarrow)$, nekrosa sel $\rightarrow$. Pewarnaan HE. 

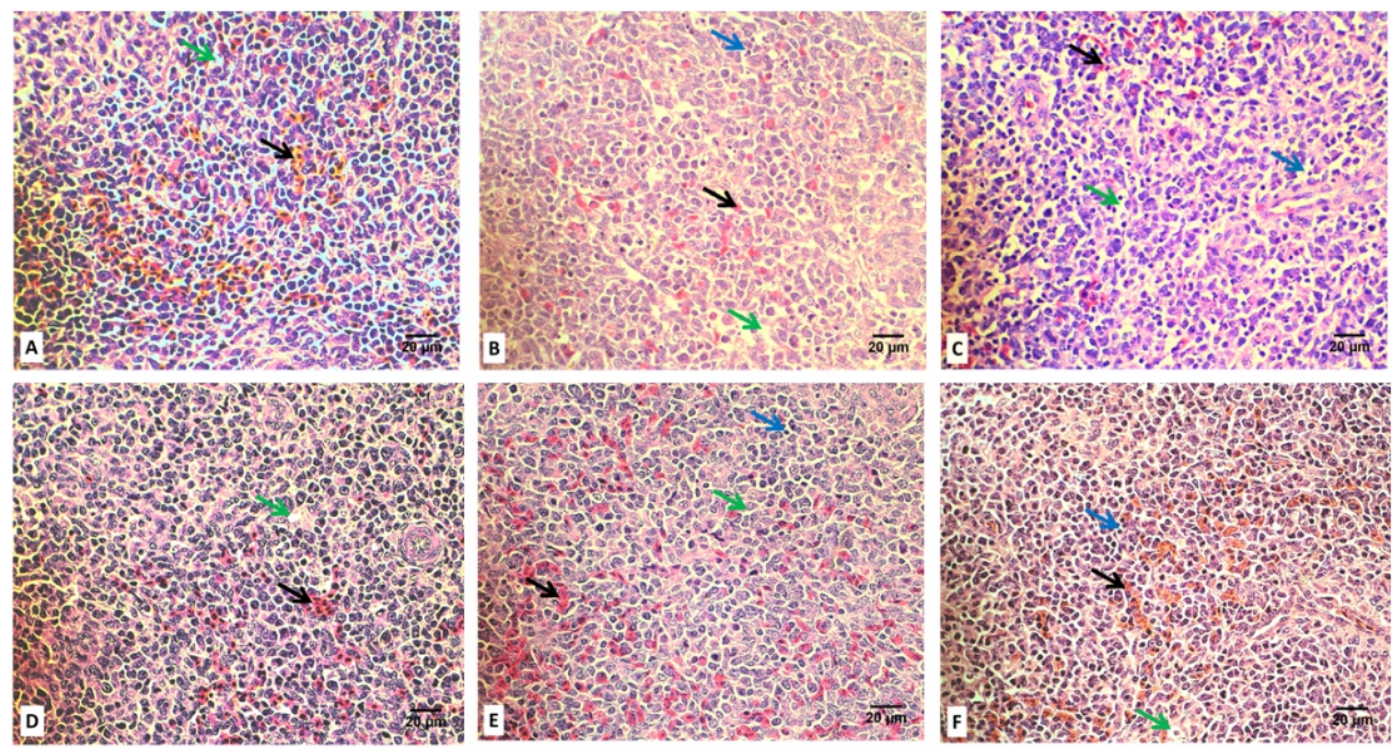

Gambar 4. Foto mikrografi organ limpa ayam dengan program vaksinasi IBD 1 kali umur 8 hari (A), umur 15 hari (B), 23 hari (C); dengan program vaksinasi IBD 2 kali umur 8 hari (D), umur 15 hari (E), dan umur 23 hari (F). Hemoraghi $(\rightarrow)$, udema $(\rightarrow)$, deplesi sel $(\rightarrow)$. Pewarnaan HE.
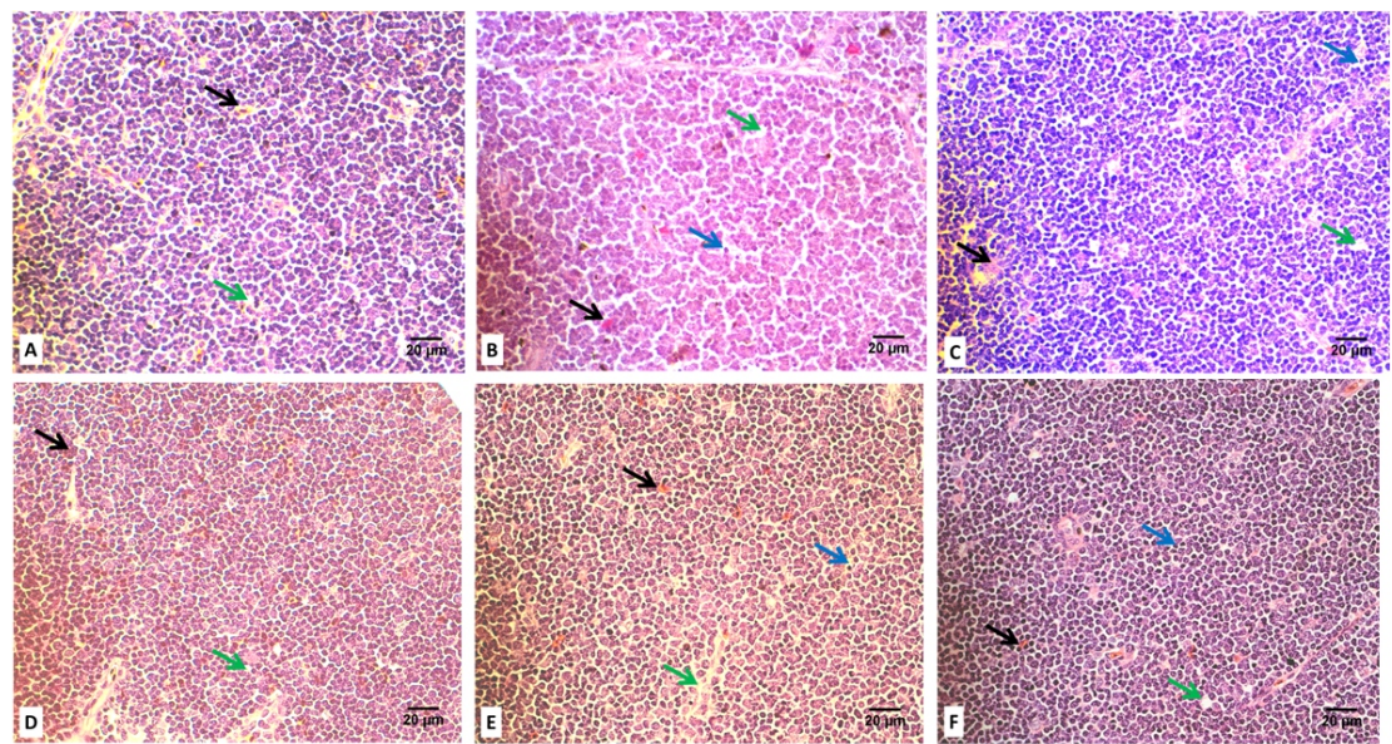

Gambar 5 Foto mikrografi organ timus ayam dengan program vaksinasi IBD 1 kali umur 8 hari (A), umur 15 hari (B), 23 hari (C); dengan program vaksinasi IBD 2 kali umur 8 hari (D), umur 15 hari (E), dan umur 23 hari (F). Hemoraghi $(\rightarrow)$, udema $(\rightarrow)$, reruntuhan sel $(\rightarrow)$. Pewarnaan HE.

Hasil penilaian secara deskriptif terhadap lesio organ limfoid dengan pewarnaan HE disajikan pada Tabel 2 .

Lesio histopatologi pada ayam umur 8 hari untuk kedua program vaksinasi terlihat tidak berbeda nyata $(\mathrm{P}<0.05)$. Diduga adanya peran maternal antibodi sehingga lesio yang terlihat lebih sedikit dibandingkan hari ke 15 dan 23 untuk kedua program vaksinasi. Homer et al. (1992) dalam penelitiannya mengemukakan bahwa level maternal antibodi yang diukur dengan menggunakan enzyme-linked immunosorbent assay (ELISA) pada ayam broiler dapat melindungi ayam hingga umur 12 hari, antibodi terhadap IBD menurun hingga tidak protektif (titer 
antibodi dibawah 1.000) pada umur 16 sampai 20 hari. Lesio IBD seperti nekrosis limfoid, infiltrasi netrofil dan makrofag, dan stromal edema pertama kali terlihat pada ayam umur 24 hari yang diberi vaksin dan tidak diberi vaksin (Homer et al., 1992). Hal ini dapat menjelaskan kejadian subklinis IBD pada ayam kurang dari 3 minggu dimana ekspresi reseptor yang terlihat dengan metode IHK menggunakan antibodi anti reseptor sel LSCC-BK3 tidak berbeda nyata $(\mathrm{P}<0.05)$ pada umur 8 dan 15 hari pada kedua program vaksinasi namun kejadian lesio pada kedua kelompok umur tersebut untuk kedua program vaksinasi berbeda nyata $(\mathrm{P}<0.05)$.

Tabel 2. Skor lesio histopatologi bursa Fabricius ayam yang mendapat 1 atau 2 kali vaksinasi IBD

\begin{tabular}{|c|c|c|c|c|c|c|}
\hline \multirow[b]{2}{*}{ Organ } & \multirow[b]{2}{*}{$\begin{array}{l}\text { Umur } \\
\text { (hari) }\end{array}$} & \multirow[b]{2}{*}{$\begin{array}{l}\text { Jumlah } \\
\text { ayam } \\
(\mathrm{n}=6)\end{array}$} & \multicolumn{4}{|c|}{ Skor lesio histopatologi pada program vaksinasi IBD } \\
\hline & & & $\begin{array}{c}1 \text { kali } \\
\text { (jumlah } \\
\text { skor) }\end{array}$ & $\begin{array}{c}\text { *Asymp. } \\
\text { Sig. } \\
(\overline{\mathrm{P}} 0.005)\end{array}$ & $\begin{array}{l}2 \text { kali } \\
\text { (jumlah } \\
\text { skor) }\end{array}$ & $\begin{array}{c}\text { *Asymp Sig. } \\
(\overline{\mathrm{P}} 0.005)\end{array}$ \\
\hline $\begin{array}{c}\text { Bursa } \\
\text { Fabricius }\end{array}$ & $\begin{array}{c}8 \\
15 \\
23\end{array}$ & 18 & $\begin{array}{r}6^{\mathrm{Aa}} \\
23^{\mathrm{Ab}} \\
23^{\mathrm{Ab}}\end{array}$ & 0.001 & $\begin{array}{l}6^{\mathrm{Aa}} \\
12^{\mathrm{Bb}} \\
20^{\mathrm{Ab}}\end{array}$ & 0.000 \\
\hline Limpa & $\begin{array}{c}8 \\
15 \\
23 \\
\end{array}$ & 18 & $\begin{array}{r}7^{\mathrm{Aa}} \\
21^{\mathrm{Ab}} \\
17^{\mathrm{Ab}}\end{array}$ & 0.003 & $\begin{array}{c}6^{\mathrm{Aa}} \\
11^{\mathrm{Bab}} \\
18^{\mathrm{Ab}}\end{array}$ & 0.001 \\
\hline Timus & $\begin{array}{c}8 \\
15 \\
23\end{array}$ & 18 & $\begin{array}{c}8^{\mathrm{Aa}} \\
18^{\mathrm{Ab}} \\
15^{\mathrm{Ab}}\end{array}$ & 0.004 & $\begin{array}{c}6^{\mathrm{Aa}} \\
12^{\mathrm{Ab}} \\
13^{\mathrm{Ab}}\end{array}$ & 0.003 \\
\hline
\end{tabular}

${ }^{\mathrm{AB}}$ Huruf yang berbeda pada baris yang sama berbeda nyata $(\mathrm{P}<0.05)$

${ }^{\text {ab }}$ Huruf yang berbeda pada kolom yang sama berbeda nyata $(\mathrm{P}<0.05)$

\begin{tabular}{|c|c|c|c|c|c|}
\hline \multirow{2}{*}{ Organ } & \multirow{2}{*}{ Lesio histopatologi } & \multicolumn{4}{|c|}{ Skor } \\
\hline & & 1 & 2 & 3 & 4 \\
\hline \multirow{3}{*}{$\begin{array}{l}\text { Bursa } \\
\text { Fabricius }\end{array}$} & Deplesi sel & + & +++ & ++++ & +++++ \\
\hline & Udema & + & ++ & +++ & ++++ \\
\hline & Nekrosa sel & - & + & ++ & ++ \\
\hline \multirow{3}{*}{ Limpa } & Hemoraghi & + & ++ & ++ & +++ \\
\hline & Udema & + & ++ & ++ & +++ \\
\hline & Deplesi sel & - & + & ++ & +++ \\
\hline \multirow{3}{*}{ Timus } & Hemoraghi & + & ++ & ++ & ++ \\
\hline & Udema & + & ++ & ++ & +++ \\
\hline & Reruntuhan sel timus & - & + & ++ & +++ \\
\hline
\end{tabular}

Perbedaan lesio histopatologi antara kedua vaksinasi pada ketiga organ limfoid terlihat berbeda nyata $(\mathrm{P}<0.05)$ pada ayam umur 15 hari $(4$ hari post vaksinasi) dimana tingkat kerusakan yang terlihat pada vaksinasi IBD 1 kali lebih banyak dibandingkan vaksinasi IBD 2 kali (Tabel 2). Hal ini memungkinkan adanya ikatan antigen virus IBD dari vaksin aktif dengan reseptor pada permukaan sel limfosit B. Uddin et al. (2012) dalam penelitiannya menyatakan bahwa secara signifikan dengan pewarnaan HE jumlah limfosit lebih rendah pada organ limfoid ayam broiler yang diinfeksi virus IBD dibandingkan dengan yang tidak diinfeksi dan secara signifikan pula jumlah limfosit berkurang pada limpa dan timus dari ayam terinfeksi virus IBD. Hal tersebut menandakan bahwa virus IBD tidak hanya merusak limfosit pada bursa Fabricius tetapi limpa dan juga timus.

Sebaran reseptor virus IBD pada kedua 
program vaksinasi IBD terlihat memiliki pola yang sama yaitu terjadi penurunan ekspresi reseptor yang dikenali IHK pada ayam umur 15 hari (Tabel 1). Diduga sel B memori berperan pada ikatan antigenreseptor pada program vaksinasi IBD 2 kali sehingga dengan jumlah reseptor IBD yang tidak berbeda nyata program vaksinasi IBD 2 kali pada ayam memberikan gambaran histopatologi organ limfoid lebih baik dibandingkan dengan program vaksinasi 1 kali (Gambar 2). Hal ini sejalan dengan penelitian Besseboua et al. (2015) yang menyebutkan bahwa vaksinasi 2 kali perlu dilakukan agar mendapatkan perlindungan yang lebih baik terhadap IBD.

\section{Kesimpulan}

Jumlah reseptor tidak berkorelasi langsung dengan tingginya kejadian infeksi virus IBD, namun adanya reseptor spesifik memungkinkan terjadinya infeksi virus IBD pada unggas.

Ekspresi positif imunohistokimia reseptor virus IBD pada organ bursa Fabricius ayam yang mendapat vaksinasi IBD 2 kali lebih banyak dan berbeda nyata dengan ayam yang mendapat vaksinasi IBD 1 kali pada umur 23 hari.

Sebaran reseptor virus IBD pada organ limfoid ayam yang mendapat vaksin IBD 2 kali lebih banyak ditemukan pada organ bursa Fabricius.

Lesio histopatologi organ bursa Fabricius, limpa, dan timus ayam umur 15 hari dengan program vaksinasi IBD 2 kali lebih ringan dibandingkan dengan program vaksinasi IBD 1 kali.

\section{Ucapan Terima Kasih}

Ucapan terima kasih disampaikan kepada dosen pembimbing dan rekan-rekan di Laboratorium Patologi yang telah membantu terlaksananya kegiatan penelitian ini.

\section{Daftar Pustaka}

Aberts, B., Johnson, A., Lewis, J., Raff, M., Roberts, K., Walter, P. (2002). Molecular Biology of the Cell $4^{\text {th }}$ ed. Garland Science : New York.

Besseboua, O., Ayad, A., Benbarek, H. (2015). Determination of the optimal time of vaccination againts infectious bursal disease virus (gumboro) in Algeria. $J$ Vet Research. 82(1): 1-6.

Davison, F., Kaspers, B., Schat, K. A. (2008). Avian Immunology. Elsavier Ltd. USA.

Enterradossi, N., Saif, Y. M. (2008). Disease of Poultry : Infectious Bursal Disease $12^{\text {th }}$ ed. Backwell : USA.

Fantay, H., Balcha, E., Tesfay, A., Afera, B. (2015). Determining optimum time for administration of live intermediate vaccine of infectious bursal disease at Mekelle farm. J Vet Sci \& Technol. 6: 223.

Gaballa, M. M. S., Soliman, M. A., Moustafa, S. A., Nasef, S. A., El-Mashad, Ab. I. (2016). Immunopathological cell tropism detection of infectious bursal disease in broiler chickens. Global Vet. 16(1): 86-92.

Gao, H., Qi, X. L., Li, K., Gao, L. H., Gao, Y. L., Qin, L. T., Wang, Y. Q., Wang, M. X. (2011). Development of a tailored vaccine againts challenge with very virulent infectious bursal disease virus of chickens using reverse genetics. Vaccine. 29: 5550-5557.

Hirai, K., dan Calnek, B. W. 1979. In vitro replication of infectious bursal disease virus in established lymphoid cell lines and chicken B lymphocytes. Infect. Immun. 25:964-970.

Homer, B L., Butcher, G. D., Miles, R. D., Rossi, A. F. (1992). Subclinical infectious bursal disease in an integrated broiler production operation. $J$ vet Diagn Invest. 4: 406-411.

Kaufer, I., dan Weiss, E. 1976. Electron-microscope studies on the pathogenesis of infectious bursal disease after intrabursal application of the causal virus. Avian Dis. 20:483-495.

Kencana, G. A. Y., Adi, A. A. A. M., Ardana, I. B. K., Mahardika, I. G. N. K. (2011). Vaksin gumboro menyebabkan imunosupresif pada respon 
primer vaksin penyakit tetelo ayam pedaging. $J$ Vet. 12(4): 275-280.

Kim, I. J., Youn, S. K., Kim, H., Yeh, H. Y., Sharma, J. M. (2000). Characteristics of Bursal T Lymphocytes Induced by Infectious Bursal Disease Virus. J. of Virol. 74(19): 8884-8892.

Müller, H., Scholtissek, C., Becht, H. 1979. The genome of infectious bursal disease virus consists of two segments of double-stranded RNA. J Virol 31:584-589

Muller, H., Islam, M. R., Raue, R. (2003). Research on infectious bursal disease-the past, the present, and the future. Vet Microbiol. 97: 153-165.

Niepper, H., Muller, H. (1996). Susceptibility of chicken lymphoid cells to infectious bursal disease virus does not correlate with the presence of specific binding sites. J. General virol. 77: 1229-1237.

Ogawa, M., Yamaguchi, T., Setiyono, A., Ho, T., Matsuda, H., Furusawa, S., Fukushi, H., Hirai, K. (1998). Some characteristics of cellular receptor for virulent infectious bursal disease virus by using flow cytometry. Arc Virol. 143: 2327-2341.

Setiyono, A., Hayashi, T., Yamaguchi, T., Fukushi, H., Hirai, K. (2000). Detection of cell membrane proteins interact with virulent infectious bursal disease virus. J. Vet. Med. Sci. 63(2): 219-221.

Setiyono, A., Yamaguchi, T., Ogawa, M., Fukushi, H., Hirai, K. (2001). Isolation of monoclonal antibodies that inhibit the binding of infectious bursal disease virus to LSCC-BK3 cells. $J$ Vet MedSci. 63(2): 219-221.

Smith, J., Sadeyen, J. R., Butter, C., Kaiser, P., Burt, D. W. (2014). Analysis of the early immune response to infection by infectious bursal disease virus in chickens differing in their resistance to the disease. J.Virol. 89(5): 24692482. doi:10.1128/JVI.02828-14.

Tippehauer, M., Heller, D. E., Weigend, S., Rautenschlein, S. (2013). The host genotype influences infectious bursal disease virus pathogenesis in chickens by modulation of T cell responses and cytokine gene expression. DCI. 40: 1-10.

Uddin, M. M., Islam, M. S., Basu, J., Khan, M. Z. I. (2012). Distribution and quantification of lymphocytes in the major lymphoid organs of naturally gumboro infected broilers. Int. J. Morphol.30(4): 1585-1589.

Van den Berg, T. P., Eterradossi, N., Toquin, D., Meulemans, G. (2000). Infectious bursal disease (Gumboro Disease). Rev Sci Tech. Off Int Epiz. 19(2): 527-543.

Wahyuwardani, S., Agungpryono, D. R., Parede, L., Manalu, W. (2011). Penyakit gumboro : etiologi, epidemiologi, patologi, diagnosis dan pengendaliannya. Wartazoa.21(3). 